\title{
Experimental and Estimation of Vapor-Liquid Equilibria in AqueousElectrolyte System: $\mathrm{CO}_{2}-\mathrm{K}_{2} \mathrm{CO}_{3}-\mathrm{MDEA}+\mathrm{DEA}-\mathrm{H}_{2} \mathrm{O}$
}

\author{
K. Kuswandi ${ }^{1}$, Ali Altway ${ }^{1} \&$ Yuni Kurniati ${ }^{1}$ \\ ${ }^{1}$ Department of Chemical Engineering, Sepuluh Nopember Institute of Technology, Indonesia \\ Correspondence: K. Kuswandi, Department of Chemical Engineering, Sepuluh Nopember Institute of \\ Technology, Surabaya, 60111, Indonesia. E-mail: kuswandi@chem-eng.its.ac.id
}

Received: May 4, 2015

doi:10.5539/mas.v9n7p183
Accepted: June 5, 2015

Online Published: June 30, 2015

\begin{abstract}
Absorption with chemical reaction process of $\mathrm{CO}_{2}$ gas using $\mathrm{K}_{2} \mathrm{CO}_{3}$ solution or known as hot potassium carbonate promoted with amine was widely used in many chemical industries. DEA and MDEA mixture was proposed as promoter. Vapor-liquid equilibrium (VLE) data of $\mathrm{CO}_{2}-\mathrm{K}_{2} \mathrm{CO}_{3}-\mathrm{MDEA}+\mathrm{DEA}-\mathrm{H}_{2} \mathrm{O}$ system are needed for rational design and optimal operation of $\mathrm{CO}_{2}$ removal unit. The purpose of this research is to dertermine solubility data of $\mathrm{CO}_{2}$ gas in aqueous solution of potassium carbonate with DEA and MDEA as a promotor at various temperatures of $30-50^{\circ} \mathrm{C}$ with $30 \% \mathrm{~K}_{2} \mathrm{CO}_{3}, 1-3 \%$ MDEA and 1-3\% DEA. The $\mathrm{CO}_{2}$ solubility is very important property when establishing thermodynamics models for the VLE. In order to obtain the $\mathrm{CO}_{2}$ solubility, the normal procedure is to use the $\mathrm{N}_{2} \mathrm{O}$ analogy since the $\mathrm{CO}_{2}$ solubility cannot be directly measured. Solubility was measured volumetrically in absorption flask using a shaking waterbath. The increase of DEA concentration in solution gives higher Henry's constant or lower gas solubility. It also makes the empirical correlation between Henry's constant andtemperature in various concentrations of MDEA and DEA. The results of $\mathrm{N}_{2} \mathrm{O}$ analogy experiment were used to calculate the vapor liquid equilibria of $\mathrm{CO}_{2}-\mathrm{K}_{2} \mathrm{CO}_{3}-\mathrm{MDEA}+\mathrm{DEA}-\mathrm{H}_{2} \mathrm{O}$ system by using the electrolyte NRTL model. The model gives a good representation of the experimental VLE data for $\mathrm{CO}_{2}$ partial pressures with Root Mean Square Deviation (RMSD) of 5.93\%.
\end{abstract}

Keywords: $\mathrm{CO}_{2}-\mathrm{K}_{2} \mathrm{CO}_{3}-\mathrm{MDEA}+\mathrm{DEA}-\mathrm{H}_{2} \mathrm{O}$ system, solubility, vapor-liquid equilibria, $\mathrm{N}_{2} \mathrm{O}$ analogy, electrolyte NRTL model

\section{Introduction}

Carbon dioxide $\left(\mathrm{CO}_{2}\right)$ is acid gas, and it is very harmful acid.Various industries such as petrochemical, fuel oil, and natural gas industries, require the separation process of $\mathrm{CO}_{2}$ gas. One of the various methods widely used is the chemical absorption process using a basic alkanolamine solution as a solvent. The method is widely used for the removal of acid gases from natural gases. Conventionally, aqueous solutions of monoethanolamine (MEA) (Clarke, 1964; Liu et al., 1999), diethanolamine (DEA) (Li \& Lee, 1996), and methyldiethanolamine (MDEA) (Haimour \& Sandall, 1984) are examples of well-known and industrially important amine solutions.

In addition, knowledge of the amine solvent mixtures need to be developed continuously.Potassium carbonate $\left(\mathrm{K}_{2} \mathrm{CO}_{3}\right)$ has a low regeneration heat but the reaction rate is lower compared with the amine. Several studieshave shown that blending with amines can accelerate the process of absorption (Savage et al., 1984; Cullinane \& Rochelle, 2004; Thee et al., 2012).

To design a gas absorption unit, physical property such as solubility of acid gases in amine solvent is needed. Physical solubility measurements are generally carried out to determine the concentration of the absorbed gas in solution at equilibrium. If the absorbed gas react with the solvent, the equilibrium can not be physically measured. In other words, the physical solubility of $\mathrm{CO}_{2}$ gas in alkanolamine can not be measured directly. Therefore, $\mathrm{N}_{2} \mathrm{O}$ analogy is often used to estimate the solubility of $\mathrm{CO}_{2}$ gas in the amine solvent (Haimour \& Sandall, 1984; Weiland \& Browning, 1994).

A similar gas that is unreactive in the test solution was used to measure the solubility. Proportional constants are then used to calculate the solubility of $\mathrm{CO}_{2}$. Nitrogen oxide gas $\left(\mathrm{N}_{2} \mathrm{O}\right)$ was successfully used to predict the physical solubility of $\mathrm{CO}_{2}$ because it has similarity in size, shape, and electron configuration of Lennard-Jones potential to $\mathrm{CO}_{2}$ (Clarke, 1964). 
The $\mathrm{N}_{2} \mathrm{O}$ analogy is expressed in eq.1 (Haimour and Sandall, 1984):

$$
\frac{\mathrm{H}_{\mathrm{CO}_{2}}}{\mathrm{H}_{\mathrm{N}_{2} \mathrm{O}}}=\frac{{H^{\circ}}^{\mathrm{O}} \mathrm{CO}_{2}}{\mathrm{H}^{\mathrm{o}}{ }_{\mathrm{N}_{2} \mathrm{O}}}
$$

where $\mathrm{H}^{\circ} \mathrm{CO}_{2}$ and $\mathrm{H}^{\circ}{ }_{\mathrm{N}_{2} \mathrm{O}}$ are the Henry's law constants of $\mathrm{CO}_{2}$ and $\mathrm{N}_{2} \mathrm{O}$ in pure water, while $\mathrm{H}_{\mathrm{CO}_{2}}$ and $\mathrm{H}_{\mathrm{N}_{2} \mathrm{O}}$ are the Henry's law constants of $\mathrm{CO}_{2}$ and $\mathrm{N}_{2} \mathrm{O}$ in amine solution.

There are several models that can be used to estimate the solubility of $\mathrm{CO}_{2}$ in the absorption process. The electrolyte NRTL model have been used to predict the solubility of $\mathrm{CO}_{2}$ in the removal of $\mathrm{CO}_{2}$ from flue gases using a mixture of potassium carbonate-piperazine-ethanolamine (Hilliard, 2005). The electrolyte UNIQUAC model was used to predict the solubility of acid gases in Monoethanolamine (MEA) and Methyldiethanolamine (MDEA) (Kaewsichan et al., 2001).

In the presentstudy, the solubility data of $\mathrm{CO}_{2}$ in pottassium carbonate solution with MDEA-DEA mixtures as a promotor using $\mathrm{N}_{2} \mathrm{O}$ analogy were presented over the range of temperatures from 30 to $50{ }^{\circ} \mathrm{C}$. Furthermore, the $\mathrm{CO}_{2}$ partial pressures obtained from experimental results were correlated using the E-NRTLmodel.

\section{Method}

The purpose of this research is to derterminethe solubility data of $\mathrm{CO}_{2}$ gas in aqueous solution of potassium carbonate with DEA-MDEAmixtures as a promotor at various temperatures of $30-50^{\circ} \mathrm{C}$ with $30 \% \mathrm{~K}_{2} \mathrm{CO}_{3}, 1-3 \%$ MDEA and 1-3\% DEAusing the apparatus shown schematically in Figure 1. The apparatus is kept at constant temperature inside a temperature-controlled water bath. The densities of aqueous solutions were determined by using a $10-\mathrm{mL}$ pycnometer. The measurement of the solubility data was conducted in an equilibrium cell with $\mathrm{N}_{2} \mathrm{O}$ analogy method. The modified apparatus is based on that of used by Haimour and Sandall (1984). Some authors have also developed this methodto estimate the solubility data of $\mathrm{CO}_{2}$ in various amine solutions (Versteeg\& van Swaaij,1988; Al-Ghawas et al., 1989; Versteeg et al., 1992; Wang et al., 1992; Weiland \& Browning, 1994; Li \& Lai, 1995; Li \& Lee, 1996).

The principle of this method is to bring acertain volume of liquid into contact with a gas in a closed system at constant temperature and pressure. Equilibrium is reached by stirring the solution until there is no change in the volume of the gas. The volume of the gas absorbed is measured.

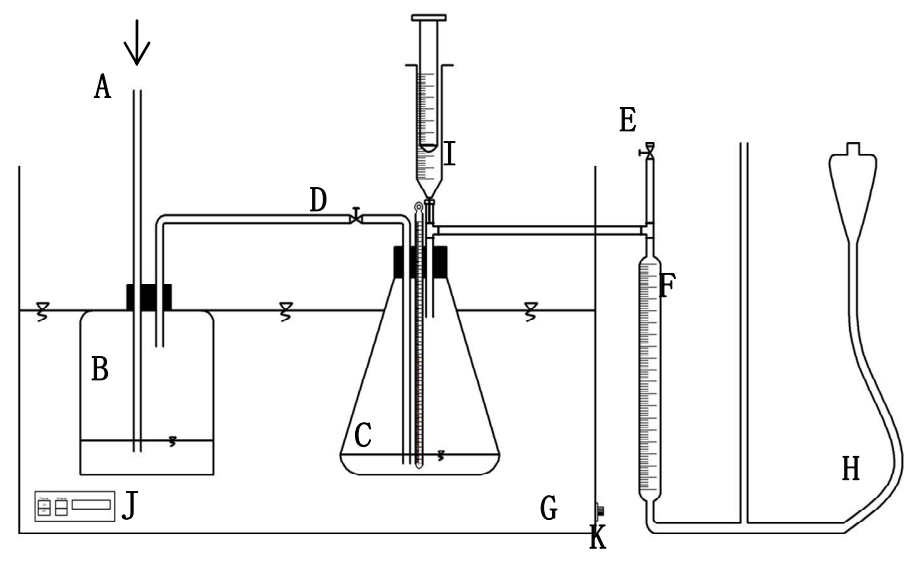
A. Gas
B. Saturation Flask
C. Absorption Flask
D. Valve
E. To Fume Hood
F. Buret $50 \mathrm{~mL}$
G. Shaking Waterbath
H. Movable barometric leg
I. Liquid Injection
J. Temperatur Display/ Power
K. Temperature Regulator

Figure1. Solubility apparatus

The solubility measurementswerecarried outas follows: A gas saturated with vapors in a saturation flask was passed through the system to purge the absorption flaskat constant temperature. Then the inletand outlet valves wereclosed. The height of the liquid water in the three branches was leveledto indicatethat the pressure in the flask was atmospheric, and its position was recorded. $20 \mathrm{~mL}$ sample of aqueoussolution of $\mathrm{K}_{2} \mathrm{CO}_{3}$-MDEA+DEA was injected into the absorption flask. After mechanical shaking for 20 to $30 \mathrm{~min}$, the surface of the waterwas maintained at the same level every few minutes, ensuring that the gas phase was at atmospheric pressure. The volume change of the system can be determined by the levels of the water in the burette. Equilibrium is reached when the volume of the gasremains constant. The volume of gas absorbed can be determined by the measured volume change and the volume of liquid sample.

After obtaining the data from the experiment, the partial pressure of $\mathrm{CO}_{2}$ was calculated using the E-NRTLmodel 
for $\mathrm{CO}_{2}-\mathrm{K}_{2} \mathrm{CO}_{3}-\mathrm{MDEA}-\mathrm{DEA}-\mathrm{H}_{2} \mathrm{O}$ system. This model consists of two contributions. First, the local interaction showedfrom the interaction between all species. The second contribution is long-range ion-ion interaction appeared due to the interaction between ionic species (Austgen et al., 1989; Chen, 1993; Pitzer, 1980).

\section{Results and Discussion}

The validation of the apparatusused in this study was conducted by using water as a solvent. The validation refers to the results of previous experiments (Versteeg \& van Swaaij, 1988; Al-Ghawas et al., 1989; Li \& Lai, 1995) and was carried out at a temperature range of $30-50{ }^{\circ} \mathrm{C}$.

Figure 2 shows the validation results of the apparatus representing the solubility data $\mathrm{N}_{2} \mathrm{O}$ in water illustrated as Henry's constants of $\mathrm{N}_{2} \mathrm{O}$ vs temperatures. Fromthe figure it is also shown the solubility data from the literatures.It can be seen that the results found in this work are in good agreement with data of Versteeg \& van Swaaij (1988) and Li \& Lai (1995), but there is a significant deviation from data of Al-Ghawas et al. (1989).

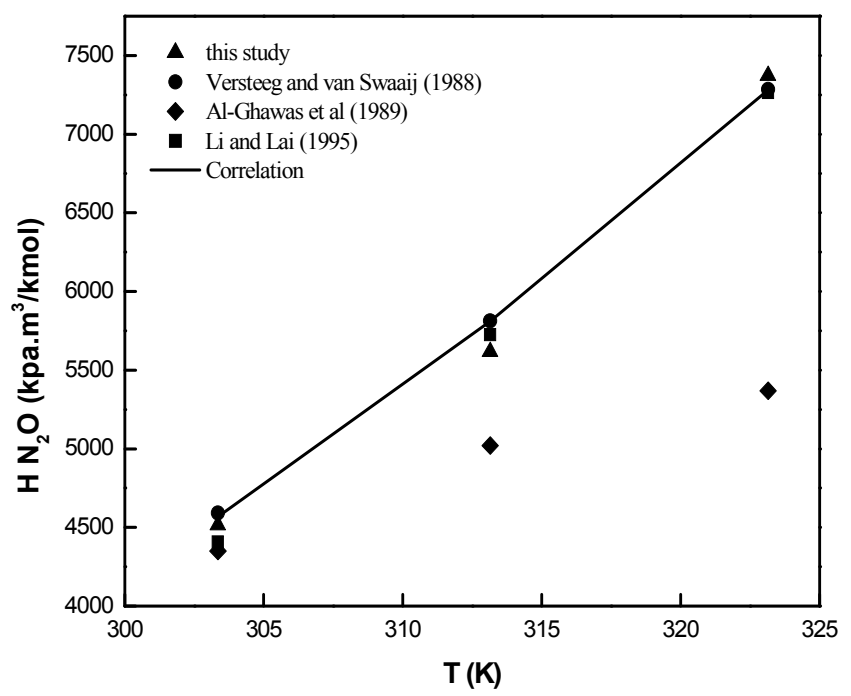

Figure 2. Solubility data of $\mathrm{N}_{2} \mathrm{O}$ in water as a functionof temperature

Physical solubility of $\mathrm{CO}_{2}$ in alkanolaminecan not be directly measured. Therefore, $\mathrm{N}_{2} \mathrm{O}$ analogy often used to estimate the solubility of $\mathrm{CO}_{2}$ in the amine solvent.In this study the solvent mixtures used are $30 \% \mathrm{~K}_{2} \mathrm{CO}_{3}, 1-3 \%$ MDEA and 1-3\% DEA with variation of temperatures in range of 30-50 ${ }^{\circ} \mathrm{C}$. The solubility of $\mathrm{N}_{2} \mathrm{O}$ and $\mathrm{CO}_{2}$ in $\mathrm{K}_{2} \mathrm{CO}_{3}+\mathrm{MDEA}+\mathrm{DEA}+$ water system at this concentrationsis shown in Figures 3 and 4. It can be seen in Figure 3 that the rise of temperature caused the increase of Henry's constant of $\mathrm{N}_{2} \mathrm{O}$.

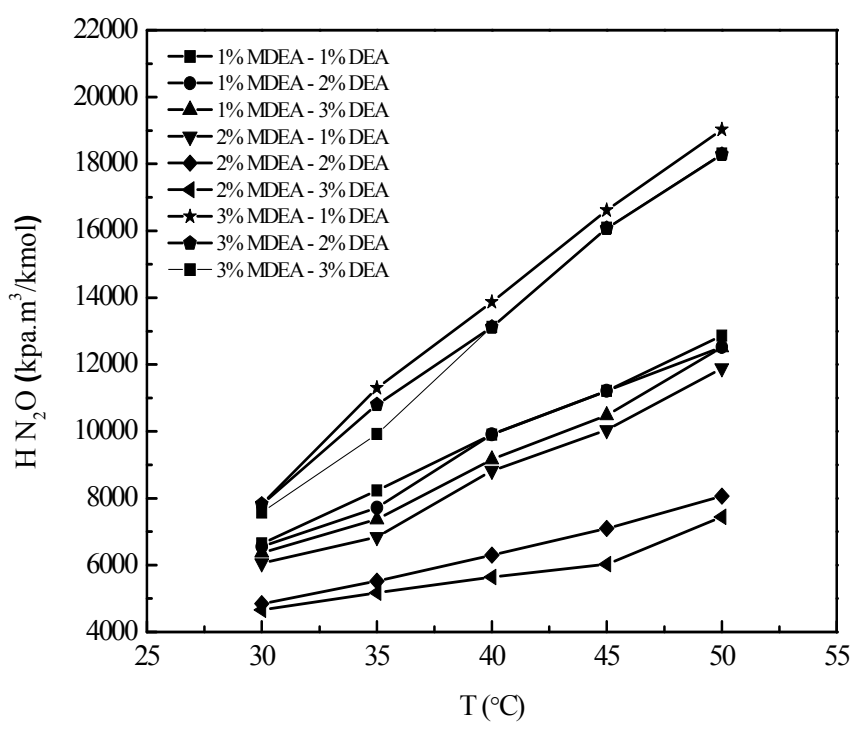

Figure 3. Solubilityof $\mathrm{N}_{2} \mathrm{O}$ in $\mathrm{K}_{2} \mathrm{CO}_{3}+\mathrm{MDEA}+\mathrm{DEA}+$ water systemfor various compositions of MDEA-DEAat temperatures $30-50^{\circ} \mathrm{C}$ 


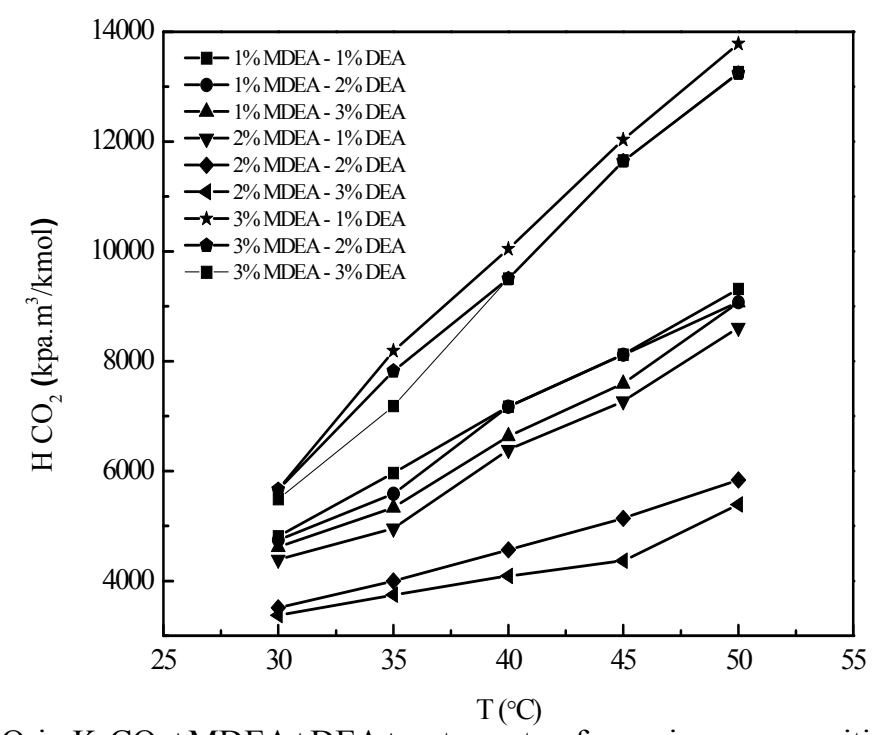

Figure 4. Solubility of $\mathrm{CO}_{2}$ in $\mathrm{K}_{2} \mathrm{CO}_{3}+\mathrm{MDEA}+\mathrm{DEA}+$ watersystemfor various compositions of MDEA-DEA at temperatures $30-50^{\circ} \mathrm{C}$

Meanwhile, the solubility data of $\mathrm{CO}_{2}\left(\mathrm{~N}_{2} \mathrm{O}\right.$ analogy) at 30\% $\mathrm{K}_{2} \mathrm{CO}_{3}, 1-3 \%$ MDEA, and 1-3\% DEA are shown in Figure 4. Physical solubility data of $\mathrm{CO}_{2}$ were obtained from the equation correlated $\mathrm{N}_{2} \mathrm{O}$ analogy into the empirical equation (eq. 2) for various concentrations of MDEA and DEA.

$$
\begin{gathered}
H=K_{1} \exp \frac{-K_{2}}{T(K)} \\
K_{1}=1,067 \times 10^{10}[M D E A]^{0,5089}[D E A]^{0,3875} \\
K_{2}=5754.896[M D E A]^{0,149}[D E A]^{-0,00835}
\end{gathered}
$$

The E-NRTL model was used tocorrelate the experimental data. The activity coefficients of $\mathrm{CO}_{2} \mathrm{were}$ calculatedusing the binaryinteraction parameters obtained by fitting the experimental data with the minimization of the deviation between calculated and experimental $\mathrm{CO}_{2}$ partial pressures. The relationships betweenthe calculated and experimental results of $\mathrm{CO}_{2}$ partial pressureand $\mathrm{CO}_{2}$ loading for $\mathrm{CO}_{2}-\mathrm{K}_{2} \mathrm{CO}_{3}-\mathrm{MDEA}+\mathrm{DEA}-\mathrm{H}_{2} \mathrm{O}$ system are presented in Figures5-9.

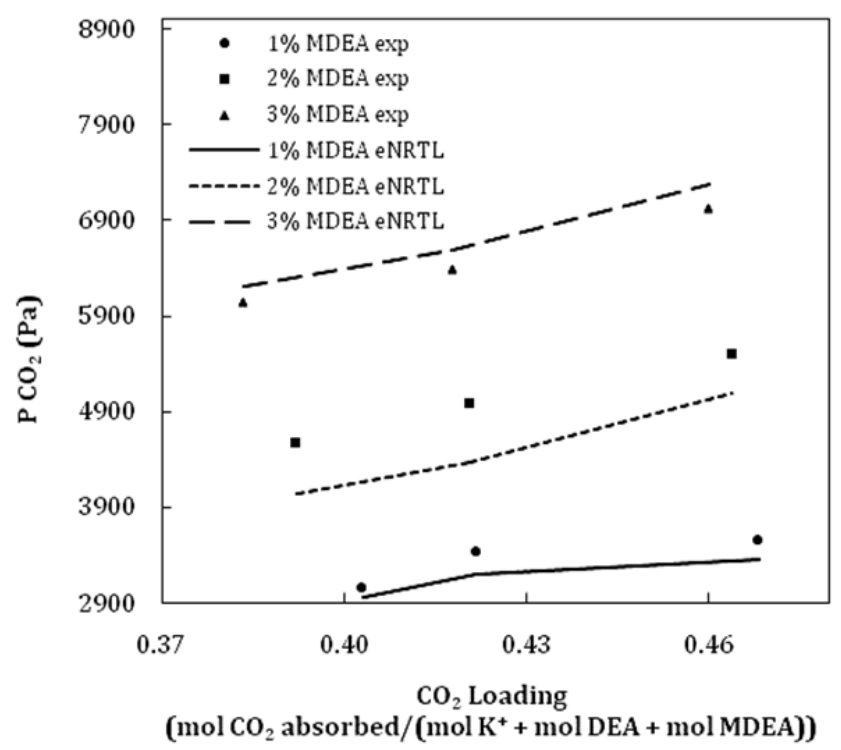

Figure 5. Therelationshipbetweenthe calculated and experimental $\mathrm{CO}_{2}$ partialpressureand $\mathrm{CO}_{2}$ loadingwith $30 \%$ $\mathrm{K}_{2} \mathrm{CO}_{3}, 1-3 \%$ DEA and 1-3\%MDEA attemperature $30^{\circ} \mathrm{C}$ 


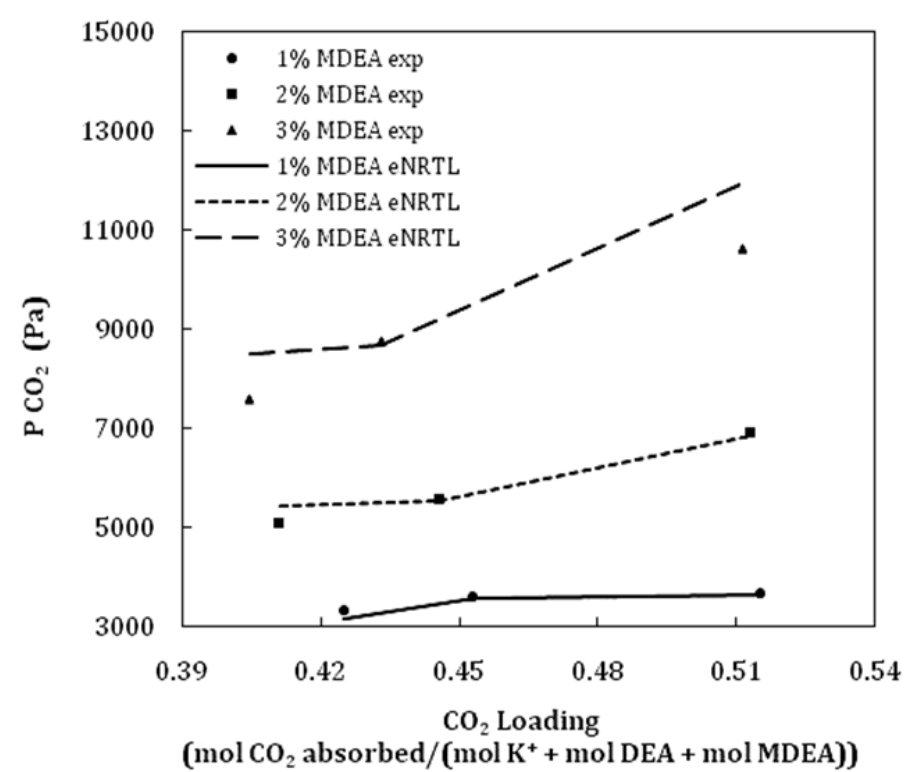

Figure 6. Therelationshipbetweenthe calculated and experimental $\mathrm{CO}_{2}$ partialpressureand $\mathrm{CO}_{2}$ loadingwith $30 \%$ $\mathrm{K}_{2} \mathrm{CO}_{3}, 1-3 \%$ DEA and $1-3 \%$ MDEA attemperature $35^{\circ} \mathrm{C}$

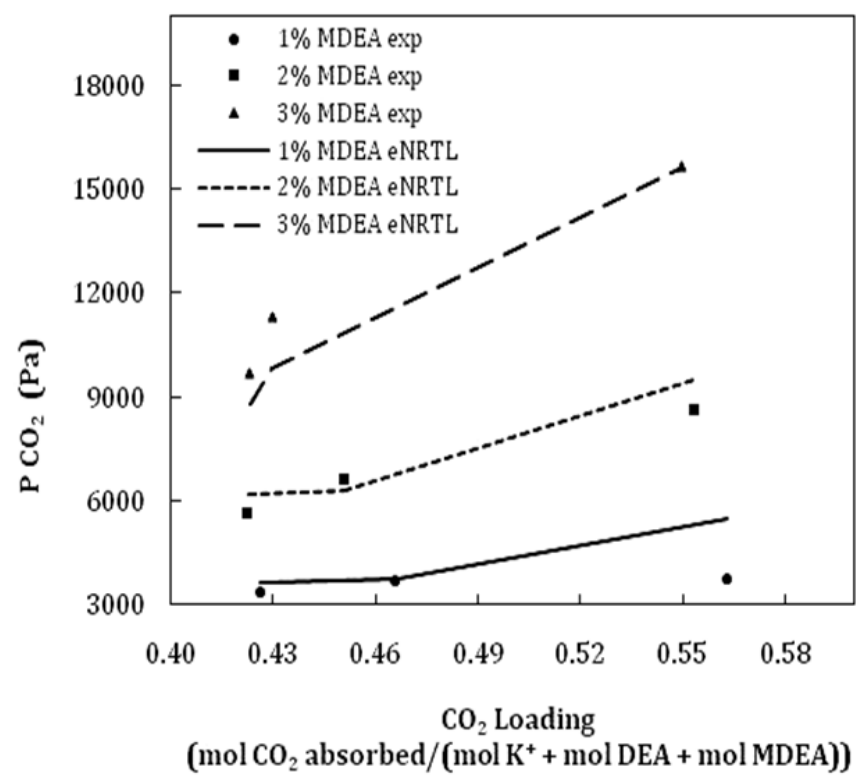

Figure 7. Therelationshipbetweenthe calculated and experimental $\mathrm{CO}_{2}$ partialpressureand $\mathrm{CO}_{2}$ loadingwith $30 \%$ $\mathrm{K}_{2} \mathrm{CO}_{3}, 1-3 \%$ DEA and $1-3 \%$ MDEA attemperature $40{ }^{\circ} \mathrm{C}$

Inthese Figures, it can be seen that at constant temperature, the partial pressure of $\mathrm{CO}_{2}$ increases with the increase of $\mathrm{CO}_{2}$ loading. The addition of MDEA concentration of 1-3\%, decreases $\mathrm{CO}_{2}$ loading. This indicates that the amount of $\mathrm{CO}_{2}$ dissolved in the solution is increased, and the partial pressure of $\mathrm{CO}_{2}$ will also be greater. From Figure 5-9, it can also be seen that the experimental results give a similar profile to those of the correlation. The addition of concentration of 1\% MDEA and 3\%DEA results in the smallest partial pressure of $\mathrm{CO}_{2}$. The model gives a good representation of the experimental VLE data for $\mathrm{CO}_{2}$ partial pressures with Root Mean Squared Deviation (RMSD) of 5.93\%.

From the description above, it can be concluded that Henry's Law constants have been obtained for the absorption of $\mathrm{CO}_{2}$ into a solution of $30 \% \mathrm{~K}_{2} \mathrm{CO}_{3}$ with DEA-MDEA mixtures, through $\mathrm{N}_{2} \mathrm{O}$ analogy. Effect of temperature rise in a solution of $30 \% \mathrm{~K}_{2} \mathrm{CO}_{3}, 1-3 \%$ MDEA and 1-3\% DEA overthe temperature range $30-50{ }^{\circ} \mathrm{C}$ 
can increase $\mathrm{CO}_{2}$ loading and partial pressure of $\mathrm{CO}_{2}$. The model gives a good representation of the experimental VLE data for $\mathrm{CO}_{2}$ partial pressures with Root Mean Squared Deviation (RMSD) of 5.93\%.

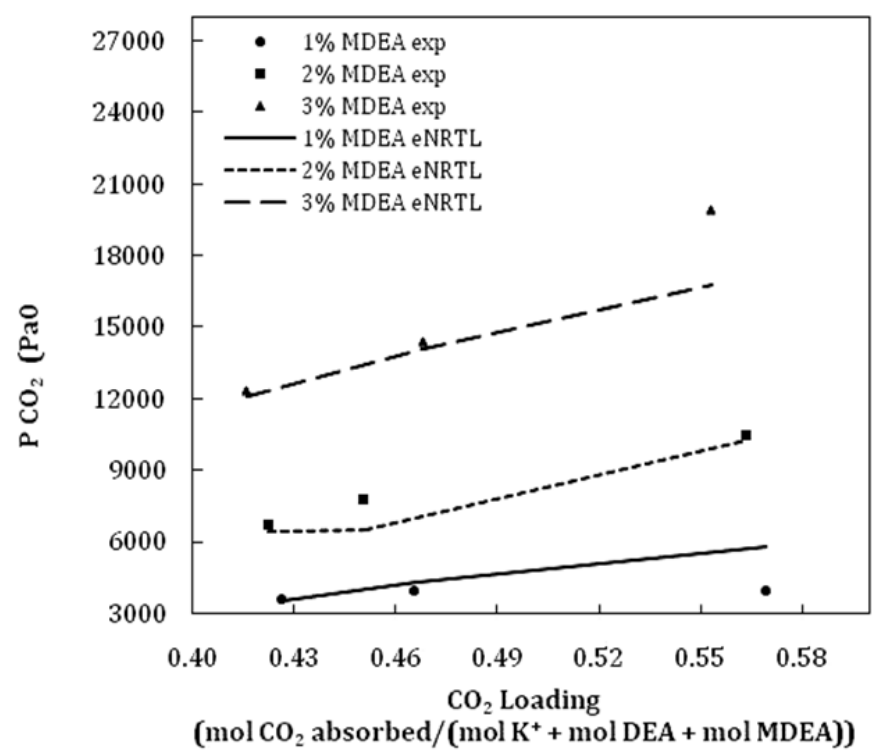

Figure 8. Therelationshipbetweenthe calculated and experimental $\mathrm{CO}_{2}$ partialpressureand $\mathrm{CO}_{2}$ loadingwith $30 \%$ $\mathrm{K}_{2} \mathrm{CO}_{3}, 1-3 \%$ DEA and $1-3 \%$ MDEA attemperature $45{ }^{\circ} \mathrm{C}$

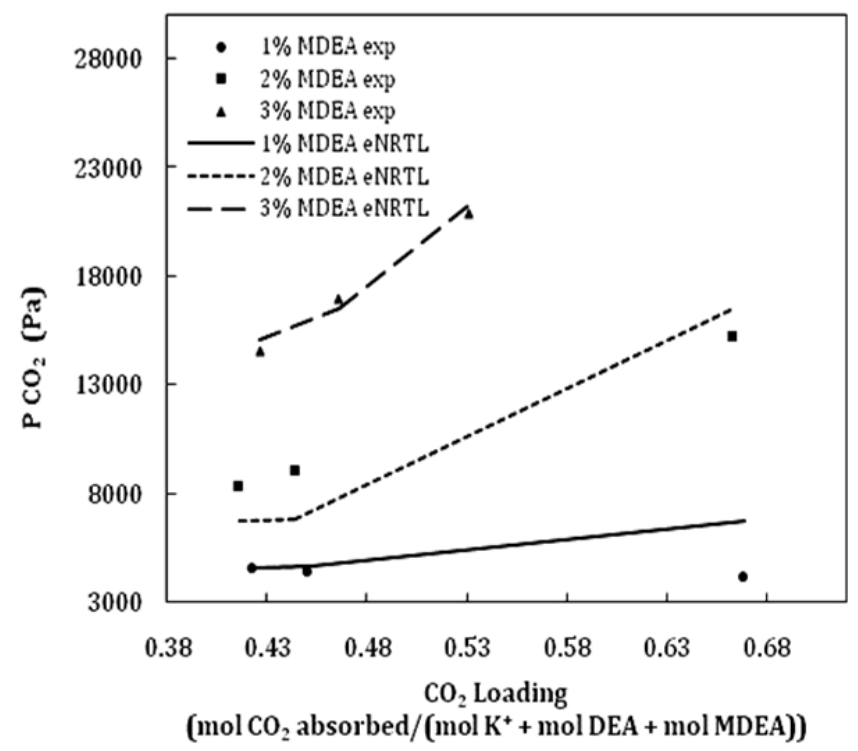

Figure 9. Therelationshipbetweenthe calculated and experimental $\mathrm{CO}_{2}$ partialpressureand $\mathrm{CO}_{2}$ loadingwith $30 \%$ $\mathrm{K}_{2} \mathrm{CO}_{3}, 1-3 \%$ DEA and 1-3\%MDEA attemperatura $50{ }^{\circ} \mathrm{C}$

\section{Acknowledgments}

The authors wish to thank sponsorship of Directorate General of Higher Education, Ministry of Education and Culture, Indonesian Government, through University Research Grant BOPTN in 2013.

\section{References}

Al-Ghawas, H. A., Hagewlesche, D. P., Rulz-Ibanez, G., \& Sandall, O. C. (1989). Physicochemical Properties Important for Carbon Dioxide. Journal of Chemical and Engineering Data, 34, 385-391. http://dx.doi.org/10.1021/je00058a004

Austgen, D. M., Rochelle, G. T., Peng, X., \& Chen, C. C. (1989). Model of Vapor-LiquidEquilibria for 
AqueousAcid Gas-AlkanolamineSystemsUsing the Electrolyte-NRTL Equation. Industrial \& Engineering Chemistry Research., 28, 1060-1073. http://dx.doi.org/10.1021/ie00091a028

Chen, C. C. (1993). A segment-based local composition model for the Gibbs energy of polymer solutions, Fluid Phase Equilibria, 83, 301-312. http://dx.doi.org/10.1016/0378-3812(93)87033-W

Clarke, J. K. A. (1964). Kinetics of Absorption of Carbon Dioxide In Monoethanolamine Solutions at Short Contact Times. Industrial \& Engineering Chemistry Fundamental, 3, 239-245. http://dx.doi.org/10.1021/1160011a012

Cullinane, J. T., \& Rochelle, G. T. (2004). Carbon dioxide absorption with aqueous potassium carbonate promoted by piperazine, Chemical Engineering Science, 59, 3619-3630. http://dx.doi.org/10.1016/j.ces.2004.03.029

Haimour, N., \& Sandall O. C. (1984). Absorption of Carbon Dioxide into Aqueous Methyldiethanolamine. Chemical Engineering Science, 39, 1791-1796. http://dx.doi.org/10.1016/0009-2509(84)80115-3

Hilliard, M. D. (2005). A predictive model for aqueous potassium carbonate/piperazine/ethanolamine for carbon dioxide removal from flue gas. Dissertation Proposal, Department of Chemical Engineering, University of Texas, Austin.

Kaewsichan, L., Al-Bofersen, O., Yesavage, V. F., \& Selim, M. S. (2001). Predictions of The Solubility of Acid Gases in Monoethanolamine (MEA) and Methyldiethanolamine (MDEA) Solutions Using The Electrolyte-UNIQUAC Model. Fluid Phase Equilibria, 183-184, 159-171. http://dx.doi.org/10.1016/S0378-3812(01)00429-0

Li, M. H., \& Lai, M. D. (1995). Solubility and Diffusivity of $\mathrm{N}_{2} \mathrm{O}$ and $\mathrm{CO}_{2}$ in (Monoethanolamine $+\mathrm{N}$-Methyldiethanolamine + Water) and in (Monoethanolamine +2-Amino-2-methyl-1-propanol + Water). Journal of Chemical and Engineering Data, 40, 486-492. http://dx.doi.org/10.1021/je00018a029

Li, M. H., \& Lee., W. C. (1996). Solubility and Diffusivity of $\mathrm{N}_{2} \mathrm{O}$ and $\mathrm{CO}_{2}$ in (Diethanolamine+ N-Methyldiethanolamine+Water) and in (Diethanolamine+2-Amino-2-methyl-1-propanol+Water). Journal of Chemical and Engineering Data, 41, 551-556. http://dx.doi.org/10.1021/je950224a

Liu, Y., Zhang, L., \& Watanasiri, S. (1999). Representing Vapor-Liquid Equilibrium for an Aqueous MEA-CO Industrial \& Engineering Chemistry Research, 38, 2080-2090. http://dx.doi.org/10.1021/ie980600v

Pitzer, K. S. (1980). Electrolytes.From dilute solutions to fused salts. Journal of the American Chemical Society, 102, 2902-2906. http://dx.doi.org/10.1021/ja00529a006

Savage, D. W., Sartori, G., \& Astarita, G. (1984). Amines as rate promotors for carbon dioxide hydrolysis. Faraday Discussions of the Chemical Society, 77, 17-31. http://dx.doi.org/10.1039/dc9847700017

Thee, H., Suryaputradinata, Y. A., Mumford, K. A., Smith, K. H., ilva, G. D., Kentish, S. E., \& Stevens, G. W. (2012). A kinetic and process modeling study of $\mathrm{CO}_{2}$ capture with MEA-promoted potassium carbonate solutions. The Chemical Engineering Journal, 210, 271-279. http://dx.doi.org/10.1016/j.cej.2012.08.092

Versteeg, G. F., \& SwaaiJ, W. P. M. (1988). Solubility and Diffusivity of Acid Gases $\left(\mathrm{CO}_{2}, \mathrm{~N}_{2} \mathrm{O}\right)$ in Aqueous Alkanolamine Solutions. Journal of Chemical and Engineering Data, 33, 29-34. http://dx.doi.org/10.1021/je00051a011

Versteeg, G. F., Littel, R. J., \& SwaaiJ, W. P. M. (1992). Solubility and Diffusivity Data for the Absorption of $\mathrm{COS}, \mathrm{CO}_{2}$, and $\mathrm{N}_{2} \mathrm{O}$ in Amine Solutions. Journal of Chemical and Engineering Data, 37, 49-55. http://dx.doi.org/10.1021/je00005a017

Wang, Y. W., Xu, S., Otto, F. D., \& Mather, A. E. (1992). Solubility of $\mathrm{N}_{2} \mathrm{O}$ in alkanolamines and in mixed solvents. The Chemical Engineering Journal, 48, 31-40. http://dx.doi.org/10.1016/0300-9467(92)85004-S

Weiland, R. H., \& Browning, G. J. (1994). Physical Solubility of Carbon Dioxide in Aqueous Alkanolamines via Nitrous Oxide Analogy. Journal of Chemical and Engineering Data, 39, 817-822. http://dx.doi.org/10.1021/je00016a040

\section{Copyrights}

Copyright for this article is retained by the author(s), with first publication rights granted to the journal.

This is an open-access article distributed under the terms and conditions of the Creative Commons Attribution license (http://creativecommons.org/licenses/by/3.0/). 